\title{
Assessment of Contraception Use among Early Married Females in Rural Districts in Giza Governorate, Egypt
}

\author{
Maha A.Mowafy ${ }^{1 *}$, Nesreen M. Kamal Elden ${ }^{2}$ \\ ${ }^{1}$ Department of Family Medicine, Faculty of Medicine, Cairo University, ${ }^{2}$ Public Health Department, \\ Faculty of Medicine, Cairo University, Egypt
}

\begin{abstract}
:
Background: Family planning improves the health outcomes of mothers and children and reduces pregnancy-related morbidity and mortality, and the economic costs of early pregnancy.

Objective: Describe the effect of the age of marriage on contraceptive behaviors.

Methods: A cross-sectional study was conducted in a systematic randomly selected five rural primary health care centers in Giza governorate, Egypt to estimate the use of family planning methods among two subgroups using an adapted questionnaire: female married before $18 \mathrm{Y}$ and that married $\geq 18 \mathrm{Y}$. A structured interview conducted among 650 females in reproductive age.

Results: Pregnancy number and family size were significantly higher among female married before 18years (3.3 \pm 1.9$)$ and (4.8 \pm 1.6$)$ versus (2.7 \pm 1.5$)$ and (4.4 \pm 1.3$)$. Family planning use after first and second child were lower among early married females $(84.3 \%)$ and $(82.5 \%)$ versus $(85.2 \%)$ and $(87.4 \%)$ of their counterparts married $\geq 18 \mathrm{Y}$ respectively with no statistically significant differences. The bivariate analysis showed that the likelihood of using a family planning method after the first child was higher among educated women and women with an educated husband than among illiterate women and women with non-educated husband [COR, 2.6; 95\% CI,1.5-4.5] and [COR,1.7; 95\% CI,1.1-2.9] respectively.
\end{abstract}

Conclusions: Family planning method use was particularly low among females married before 18 and consequently, their family size and their pregnancy number were high. Education is a significant determinant of the age of marriage and of FP use. These factors should be considered during the design of short- term and long-term family planning strategies to effectively increase family planning methods use among early married females especially in conservative contexts.

Keywords: Age of marriage, Contraception; Family planning.

\section{Introduction:}

Early marriage is the start of reproductive health problems because of the younger age to get married, the longer reproductive life of a woman, the higher the possibility of having more children. The use of contraceptives is significant for spacing and furthermore, limiting pregnancy. ${ }^{(1)}$

Early marriage and maternal health are inseparably related. Evidence shows that girls who marry before the age of 18 are more vulnerable to unwanted pregnancies, are susceptible to sexually transmitted diseases, and are at higher risk of sexual and reproductive health morbidities and maternal mortality. Each year, near 16 million young girls aged 15-19 years old give birth; around $95 \%$ of these births happen in low- and middle-income countries. ${ }^{(2)}$ Early married girls are more prone to high risk pregnancy and delivery complications during their lifetime.

Younger age of marriage, high number of children and frequent pregnancies without

*Corresponding author: E-mail: mahamowafy@kasralainy.edu.eg 
proper spacing are associated with higher risk of maternal mortality and morbidity. ${ }^{(3)}$ Stillbirths and neonatal deaths are 50\% higher among children born to early married mothers in comparison to mothers above the age of 20 years. ${ }^{(4)}$ In addition, the younger the age of the mother, the more unfavorable outcome of pregnancy is expected such as premature and low-birth weight babies.

The use of contraception is highly affected by the economic status and the education level of women. ${ }^{(5)}$ National data from 2014 Egyptian Demographic and Health Survey (EDHS), shows that the median age at first marriage among women age 25-49 years is 20.8 years among women of reproductive age. Women in rural areas marry an average about 4 years younger than women in urban areas. Although age trends at first marriage during the past 14 years show an increase of 1.3 years among married women ages 25 to 49 , about $6 \%$ of women in this age group are currently or ever married. (6)

The use of contraceptives is highly associated with several health benefits such as preventing unintended pregnancies, encouraging healthy birth spacing, reducing lifetime risk of maternal deaths, and enhancing the achievement of development goals. ${ }^{(7-10)}$ Moreover, contraceptive use plays a vital role in the demographic transitions in different countries in variable demographic conditions. ${ }^{(11)}$ Several researches have studied the variable determinant affecting the use of contraception among women in different age group. ${ }^{(12-18)}$ Nevertheless, a few number focused on the impact of age of marriage of contraceptive use.

According to the Egyptian Health Issue Survey (HIS), $96.6 \%$ of women in the age group 15-24 have knowledge of family planning (FP) methods compared to $99.9 \%$ in the age group of 25-49. ${ }^{(19)}$ On the other hand, $58.5 \%$ of presently married women age 15-49 reported the use of any method of contraception. $^{(6)}$

The use of contraceptives is highly affected by age, with a range of $21 \%$ among at present married women 15-19 to a peak of 73\% among women 35-39. Family size and number of children is an additional important determinant, as noticed from the higher percentage of women using contraceptives with 3-4 children to reach $74 \%{ }^{(6)}$

There are numerous demographic and socioeconomic characteristics that impact contraceptive behavior. This study examines age as one of the demographic factors affecting the use of contraceptives among women in reproductive age in rural areas. 
Early marriage is one of the main social problems and community norms in the Arab countries and represents a form of violence against women. According to the Egyptian Child Act 2008, the minimum age for marriage is 18 years for females and males.

According to the population census in 2017, around 27.7 million women are above the age of 18, among them, 23 million women are married; including 119000 married girls before the age of 18 . Currently $15 \%$ of adolescents' girls younger than 16 years are married (18000). ${ }^{(6)}$

In an attempt to compact early marriage, the Egyptian government imposed severe penalties on the individuals supporting marriage below this age. ${ }^{(20)}$ Moreover, the national population council launched a national strategy in 2014. The aim of which is to prevent and reduce early marriage by $50 \%$ in five years.

In spite of all the governmental and political support to combat early marriage, it is still the main problem that needs more studies for better understanding. Furthermore, social norms regarding early marriage and fertility expectations and other cultural barriers might have a role in the use of contraceptives.

\section{Methods:}

Study design: A cross-sectional study was conducted to explore the relationship between the age of marriage and FP practices among Married Women in the Reproductive Age (MWRA) in a randomly selected governorate (Giza governorate).

Settings, Sampling, and Participants: This study was conducted in all the rural districts of Giza governorate (a total of five). A systematic random sampling technique was used to select one Primary Health Care (PHC) center from a list of all $\mathrm{PHC}$ in each district. Household surveys were employed to identify influencers upon care- seeking. However, data were collected on a practice base from PHC clients' because the researchers face substantial challenges during the conduction of household surveys in less developed regions.

Lack of detailed maps, difficult access to houses locations and lack of valid addresses are the main challenges. ${ }^{(21)}$ The sample size was estimated to determine a prevalence of child marriage among married Women in Reproductive Age (MWRA) of $6 \%,{ }^{(12)}$ with a $2 \%$ acceptable margin of error and $97 \%$ level of confidence. The estimated sample size is 664, after adjustment for non-response; the sample size increased to 670 MWRA. 
Inclusion criteria: All married women in the age group (15-49 years) attending primary health care centers and approved to participate in the study were enrolled.

Exclusion criteria: Unmarried women and those outside the reproductive age range (1519 years).

Data were collected during October 2018 to March 2019. The interviews were targeting MWRA attending PHC. The interviews conducted twice a week with an average of 20 purposively selected MWRA per day in the PHC's waiting area.

Data collection: The interview questionnaire was adapted from a Korean study that investigated the relationship between fertility and thirteen variables. The questions that were relevant to the aim of our research were selected from the original questionnaire. ${ }^{(22)} \mathrm{A}$ structured interview using a questionnaire including questions targeting the following areas:

- Background characteristics: Age, education, parents' education, and respondent's family size.

- Marital characteristics: Age at first marriage, husband age, husband age at first marriage and husband education;

- Family planning practices: contraceptive use and timing, sources, types of contraceptive method and number of pregnancies
A pilot study was conducted on 50 subjects (approximately $10 \%$ of the sample size) to pretest the questionnaire and changes were made accordingly.

\section{Data management and statistical analysis:}

An electronic database for the questionnaires' answers built using Epi Ingo 3.5.3[Centers for Disease Control and Prevention (CDC)], and the data entry was done twice by NMK and MAM to ensure accuracy in data entry.

All of the statistical analyses were carried out using the IBM SPSS (Statistical Package for the Social Science; IBM Corp, Armonk, NY, USA) release 22 for Microsoft Windows for data analysis). The internal consistency (reliability) among items was tested and Cronbach's $\alpha$ was determined to be 0.65 .

A descriptive analysis was executed for all variables. An independent student $t$ test was used to compare quantitative variables according to early marriage (before $18 \mathrm{Y}$ ) and late marriage $(\geq 18 \mathrm{Y})$. A chi square test was used to analyze the association between categorical variables. P-values and 95\% confidence interval $(\mathrm{CI})$ for odds ratio $(\mathrm{COR})$ was used to judge the significance of the association in the bivariate analysis. Odds ratio (OR) are used cross-sectional studies to measure the association between an exposure 
and an outcome. OR $>1$ means that the exposure is associated with higher odds of the outcome. (23)

\section{Ethical considerations:}

The study conducted after explaining the importance and the objectives of the study to the participants. Only, those who agreed were included. A detailed consent was obtained from all the mothers before participation in the study. Preserving confidentiality and the participants' right to withdraw at any time were considered throughout the study, according to Helsinki declarations of biomedical ethics.

\section{Results:}

The results of 650 interviews (97\% response rate) were described in the following 2 main sections: Child marriage and FP practices. Age of marriage and contraceptive use are predictors of fertility. ${ }^{(22)}$ However, contraceptive use varies significantly in developed and undeveloped countries.

In the later, a drop in fertility is happening because of an increase in the marriage age, due to increases in education and a legal effort through legislation to prevent early marriages. The results described and quantified the relations between those variables: age of marriage, contraceptive use, and education.

\section{Child Marriage}

Nearly one third $(35 \%)$ of women in our sample were married before the age of $18 Y$, the minimum legal age at first marriage in Egypt. Less than one quarter $(24.1 \%)$ of those married early agree that girls should marry before $18 \mathrm{Y}$. The feelings of women who were married before $18 \mathrm{Y}$ were illustrated in (Figure-1). Table (1) presents the relations between the age of marriage and characteristics of participants, followed by Table-2 that studies the relations between education and age of marriage

Figure-1 shows that more than twothirds of the study participants $(67.1 \%)$ feel happy in their marriage, $(24.1 \%)$ feel nothing and only $(8.5 \%)$ had a severe and moderate objection. The mean age difference between women and their spouses were greater for those who were married early $(7.5 \pm 4.8)$ than for those who were married late (5.2 \pm 3.8$)$.

The women married before 18 had a higher mean of pregnancy number $(3.3 \pm 1.9)$ than their counterparts those who were married $\geq 18$ Y $(2.7 \pm 1.5)$. Those who were married late were more likely to have a higher mean age at first pregnancy $(21.2 \pm 2.9)$ and live with smaller family size $(4.4 \pm 1.3)$ than those who married early (17.2 \pm 2.4$)$ and (4.8 \pm 1.6$)$ respectively. All these differences 
were highly statistically significant $(\mathrm{P} \leq 0.001)$ as shown in Table-1.

Table (2) illustrates the effect of education on the age of marriage. Education is a key determinant in the timing of marriage. About $90 \%$ of those married $\geq 18 \mathrm{Y}$ were educated versus (79\%) of early married girls. Mother and father education of those married early was lower than their counterparts $(14 \%$ \& $27 \%)$ versus $(35 \% \&(48 \%)$ respectively. These differences were statistically significant.

Family planning practices: The impact of age of marriage on contraceptive use examined in (Table-3). Methods of FP used presented by age of marriage in (Figure-3). Finally, the effects of age of marriage and of education on contraceptive use studied in (Table-4).

Contraceptive use was greater among those married late (87.4\%) and (85.2\%) after second and first child than among those married before $18 \mathrm{Y}(82.5 \%)$ and $(84.3 \%)$ respectively with no statistically significance differences. Governmental sources were the first choice of both groups (82.5\%) and $(68.1 \%)$ versus $(17.5 \%)$ and $(31.9 \%)$ use FP methods from other sources and these differences were statistically significant $(\mathrm{P}=0.001)$ as shown in Table-3.
Figure (2) shows the FP methods use by age of marriage. IUD was the most common method used in both groups, followed by the pills. Capsules and Condoms were the less commonly methods used in both groups. Table (4) examines the effect of education and age of marriage on contraceptive use. Education is a significant determinant of FP use.

The bivariate analysis showed that the likelihood of using a contraceptive method after the first child was higher among educated women and women with an educated husband than among illiterate women and women with non-educated husband [COR, $2.6 ; 95 \% \mathrm{CI}, 1.5-4.5]$ and $[\mathrm{COR}, 1.7 ; 95 \%$ CI,1.1-2.9] respectively.

\section{Discussion:}

This study presents an overview of family planning practices among married women in the reproductive age group living in rural areas. Overall, we found that the use of the FP method was lower among early married before 18 years as compared to those married after the age of 18 years.

Among the studied population the mean age of early marriage $<18$ was 16 -year-old, representing $35 \%$ of the study sample. Around one-quarter of the early married studied women $24.1 \%$ think that a girl should marry 
before the age of 18 years. Comparatively to the EHIS, where only $4 \%$ of women in the reproductive age group (15-49) consider it best for a girl to marry before her 18th birthday, which is the legal age at marriage in Egypt. ${ }^{(19)}$ This could be attributed to the fact that this study was conducted in a rural community where early marriage is a strong social norm.

Early marriage leads to early pregnancy evidenced by reported age of first pregnancy to be 17 by studied women married $<18$ years. A pregnancy very early in life is an outcome of different factors that lead to a failure of FP. This will result in a bigger family size of $4.8 \pm 1.6$ and a higher number of pregnancies $3.3 \pm 1.9$ as clarified by the result of the study. The EHIS shows that $91.7 \%$ of women age 15-49 years approving the use of FP methods after the first birth and $89 \%$ of those living in rural areas within the same age group. This supports the findings of this study where $84.3 \% \& 85.2 \%$ of early married $<18$ years and late married $\geq 18$ years studied women respectively used a FP method after their first birth. ${ }^{(19)}$

Different studies have revealed that community and cultural factor do affect women's reproductive health behaviors and the use of contraceptives, even if marital status and parity have been identified as important individual characteristics. ${ }^{(22,23)}$ Fertility desire is highly affected by gender norms in the community. It also reflects on the use of contraceptives by women, which could not be accepted except after the first child. ${ }^{(19,24,25)}$ These results propose an additional negative influence of cultural and social norms on the FP practice of early married girls.

In our study, the prevalence of using Intra-Uterine Device (IUD) tends to be higher in both groups $56.3 \%$ in early married versus $55.5 \%$ in married after 18 years group, followed by $35.3 \%$ \& $35.5 \%$ for pills and $4.2 \% \& 2.8 \%$ for each group respectively. The majority of both groups get the FP methods from the public sources reflecting the EDHS findings were the IUD remains the preferred method. Overall, the 2014 EDHS findings showed that $59 \%$ of presently married women in Egypt are using a contraceptive method. IUD is the most commonly used contraceptive method, followed by the pill and injectables.

It is clear that education is a critical factor affecting both the age of marriage and the use of FP methods. Based on the result of the current study $87 \%$ of the educated women (irrespective of their educational level) practiced FP. This goes hand in hand with the 
significant difference between $78.6 \%$ of early married girls reporting being educated in comparison to $89.9 \%$ of married women after 18 and being educated. Several studies have been done on the same context, that there is a significant association between the educational level and the use of contraceptives.

There is a relationship of the level of education with the use of contraceptive methods in couples of childbearing-aged $<20$ years. Education is a conscious and systematic effort that lasts a lifetime in order to divert the knowledge from one person to another ${ }^{(22)} \mathrm{A}$ person who has received a better education or higher are usually more able to accept new things that would be considered advantageous for him. Conversely, if a person's education is low, then he will be more difficult to accept new things than those who are highly educated. $^{(22)}$

Generally, girls got married to men with a significant age difference and got pregnant immediately after they get married. In rural communities with big age difference and absence of women control on her decisions and ability to practice her reproductive health rights specially in relation to time, type of seeking services she is unable to make the decision or the choice on using FP methods.
The current study revealed a significant difference in spousal age difference between early married and married after 18 years age groups; $7.5 \& 5.2$ respectively. Additionally, husband education showed a significant difference between $75 \%$ in the married groups before 18 years and $85.4 \%$ for those married after 18 years.

The above finding is supported by the results of the bivariate statistics done by Abdul-Jalil Amri (2018) in his study Contraceptive use among the early marriage couples in Indonesia which explain that, the role of a husband supporting his wife to use contraception at the beginning of their marriage 5.2 times stronger than if she is not supported.

Several studies done in the same area states that there is a significant relationship between husband support and the use of contraceptives in women who married at an early age in the Aikmel Sub-District East Lombok District. ${ }^{(23)}$ One else also states there is a relationship between husband support the use of hormonal contraceptives. Clients provided with support by the husband will be using contraceptives continuously while that does not have the support of a husband would be less of contraception users. ${ }^{(19)}$ 
Limitations of the study: There are some limitations in this study that should be addressed in future research as time constrains during conducting the interviews and overcrowding in the waiting area in the health facilities. In addition, some important variables such as women's socioeconomic status, type of family, the role of males, and the use of injectable and level of awareness on contraceptive methods were not explored in the current study.

There are two main approaches to data collection in research: qualitative and quantitative research. Qualitative methods are used to understand people's experiences, attitudes, and behaviors. However, qualitative researches couldn't be extended to a wider population with the same degree of certainty that quantitative analysis can. In addition, framing and collecting qualitative questions is not an easy task. It requires a deep understanding of the culture we are studying and experiences what it is like to be part of it.

It requires flexibility, deciding about what needs to be asked in this location as well as what you can ask. For that, a combination of quantitative and qualitative approaches gives a better understanding of health-related issues and is advised in future researches. ${ }^{(26)}$
Conclusion: The use of the FP method by married women below the age of 18 is lower than those married after the age of 18 leading to a bigger family size \& higher number of children. The use of the FP method is significantly affected by the education level of both women and men. These factors can directly affect the functioning of family planning programs and can be used to support family planning programs indirectly, partially because their position is also significant.

Additionally, all these areas need to be taken into account in developing family planning strategies to well increase the use of modern contraceptive among early married girls especially in rural areas.

Acknowledgement: The authors express their thanks to Amal Gamal from the Family Medicine Department for her help in different steps of the research such as data collection and data entry.

Source of funding: There is no source of funding.

Conflict of Interest: There is no conflict of interest identified.

\section{References:}

1. The National Population and Family Planning Agency, Central Statistics Agency and the Minister of Health: 
Preliminary Report Demographic and

Health Survey of Indonesia. Jakarta. 2012.

2. World Health Organization: Early Marriages, Adolescent and Young Pregnancies. Report by the Secretariat to the WHO Executive Board, 130th session, Provisional agenda item 6.4 (EB 130/12), 2011 .

3. United Nations Population Fund: Giving Girls Today and Tomorrow: Breaking the cycle of adolescent pregnancy, UNFPA, New York, 2007.

4. World Health Organization: Fact Sheet on Adolescent Pregnancy, WHO, Geneva, 2012. Available at: http://www.who.int/mediacentre/factsheets /fs364/en/index.html, last accessed 23 February 2018.

5. United Nations: Million Development Goals, Goal5:Improve Maternal Health Target 5a\& b. Available at:: http://www.un.org/millenniumgoals/matern al.shtml, last accessed 23 September 2019.

6. El-Zanaty F, Way AA. Egypt Demographic and Health Survey, 2014.

7. Cates Jr W. Family planning: the essential link to achieving all eight Millennium Development Goals. Contraception. 2010;81:460-1.
8. Stover J, Ross J. How increased contraceptive use has reduced maternal mortality. Matern Child Health J. 2010;14:687-95.

9. Bongaarts J, Cleland J, Townsend JW, Bertrand JT, Gupta MD. Family planning programs for the 21st century: rationale and design. New York: The Population Council, Inc; 2012.

10. Ahmed S, Li Q, Liu L, Tsui AO. Maternal deaths averted by contraceptive use: an analysis of 172 countries. Lancet. 2012;380:111-25. Available at: http://dx.doi.org/10.1016/S01406736(12)60478-4.

11. Lesthaeghe R. The unfolding story of the second demographic transition. Paper presented at the conference on Fertility in the History of the 20th Century-Trends, Theories, Public Discourses, and Policies. 2010. Available at: http://www.psc.isr.umich.edu/pubs/pdf/rr1 0-696.pdf. Last accessed 18 June 2016.

12. Stephenson R, Beke A, Tshibangu D. Contextual influences on contraceptiveuse in the Eastern Cape, South Africa. Health \& Place. 2008;14:841-52.

13. Dynes M, Stephenson R, Rubardt M, Bartel D. The influence of perceptions of community norms on current contraceptive 
use among men and women in Ethiopia and Kenya. Health \& Place. 2012;18:76673.

14. Peer N, Morojele N, London L. Factors associated with contraceptive use in a rural area in Western Cape Province. S Afr Med J. 2013;103(6): 406-12.

15. Izale K, Govender I, Fina JPL, Tumbo J. Factors that influence contraceptive use amongst women in Vanga health district, Democratic Republic of Congo. Afr J Prim Health Care Fam Med. 2014;6(1): E1-7.

16. Colleran H, Mace R. Social network- and community-level influences on contraceptive use: evidence from rural Poland. Proc R Soc B. 2015;282: 20150398.

http://dx.doi.org/10.1098/rspb.2015.0398.

17. Onipede W. Religious influence on nonuse of modern contraceptives among Women in Nigeria: comparative analysis of 1990 and 2008 NDHS. J Biosoc Sci. 2015;47:593-612.

18. Blackstone SR. Women's empowerment, household status and contraception use in Ghana. J Biosoc Sci. 2017 Jul;49(4):423434.

19. El-Zanaty F, Way AA. Egypt Health Issue Survey, 2015.
20. The Official Journal issue no. 13supplement of 28 March 1996; amended by Law no. 126 of 2008, Official Journal issue no. 24-bis of 15 June 2008, and issue no. 28 of 10 July 2008.

21. Krishnamurthy R, Frolov A, Wolkon A, Eng JV, Hightower A. Application of preprogrammed PDA devices equipped with GPS to conduct paperless household surveys in rural Mozambique. InAMIA annual symposium proceedings 2006 (Vol. 2006, p. 991). American Medical Informatics Association.

22. Kim MI, Rider RV, Harper PA, Yang JM. Age at marriage, family planning practices, and other variables as correlates of fertility in Korea. Demography. 1974 Nov 1;11(4):641-56.

23. Szumilas M. Explaining odds ratios. Journal of the Canadian academy of child and adolescent psychiatry. 2010 Aug;19(3):227.

24. Ngome E, Odimegwu C. The social context of adolescent women's use of modern contraceptives in Zimbabwe: a multilevel analysis. Reprod Health. 11:64.; 2014.

25. Ochako R, Mbondo $\mathrm{M}$, Aloo $\mathrm{S}$, et al. Barriers to modern contraceptive methods uptake among young women in Kenya: a 
qualitative study. BMC Public Health. 2015; 15:118.

26. Atieno OP. An analysis of the strengths and limitation of qualitative and quantitative research paradigms. Problems of Education in the 21st Century. 2009 May 1;13(1):13-38 
Table (1): Characteristics of married women in reproductive age, by timing of marriage

\begin{tabular}{|c|c|c|c|}
\hline & $\begin{array}{c}\text { Married Early } \\
\quad(\mathrm{N}=\mathbf{2 2 4})\end{array}$ & $\begin{array}{c}\text { Married } \geq 18 Y \\
(\mathrm{~N}=426)\end{array}$ & $\mathbf{P}_{\text {values }}^{\dagger}$ \\
\hline & $\mathbf{M} \pm$ SD & $\mathbf{M} \pm \mathbf{S D}$ & $\leq 0.001$ \\
\hline - Age & $26.9 \pm 8.1$ & $28.4 \pm 5.9$ & $\leq 0.001$ \\
\hline - Age at first marriage & $16.0 \pm 0.9$ & $20.6 \pm 2.6$ & $\leq \mathbf{0 . 0 0 1}$ \\
\hline - Spousal age difference & $7.5 \pm 4.8$ & $5.2 \pm 3.8$ & $\leq 0.001$ \\
\hline - Age at first pregnancy & $17.2 \pm 2.4$ & $21.2 \pm 2.9$ & $\leq \mathbf{0 . 0 0 1}$ \\
\hline - $\quad$ Pregnancy number & $3.3 \pm 1.9$ & $2.7 \pm 1.5$ & $\leq \mathbf{0 . 0 0 1}$ \\
\hline - Family size & $4.8 \pm 1.6$ & $4.4 \pm 1.3$ & $\leq \mathbf{0 . 0 0 1}$ \\
\hline
\end{tabular}

†student's t test 
Table (2): Distribution of participants by education and age of marriage

\begin{tabular}{|c|c|c|c|}
\hline & $\begin{array}{c}\text { Married Early } \\
(\mathbf{N}=\mathbf{2 2 4})\end{array}$ & $\begin{array}{c}\text { Married } \geq \mathbf{1 8 Y} \\
(\mathbf{N = 4 2 6})\end{array}$ & P value $^{\dagger}$ \\
\hline $\begin{array}{c}\text { Education } \\
\text { - Yes }\end{array}$ & $\begin{array}{c}176(78.6 \%) \\
48(21.4 \%)\end{array}$ & $\begin{array}{c}383(89.9 \%) \\
43(10.1 \%)\end{array}$ & $\leq 0.001$ \\
\hline $\begin{array}{c}\text { Husband education } \\
\text { - Yes }\end{array}$ & $168(75 \%)$ & $364(85.4 \%)$ & $\leq 0.001$ \\
\hline No & $56(25 \%)$ & $62(14.6 \%)$ & $\leq 0.001$ \\
\hline $\begin{array}{c}\text { Mother education } \\
\text { - Yes }\end{array}$ & $31(13.8 \%)$ & $147(34.5 \%)$ & \\
\hline Father education & $193(86.2 \%)$ & $279(65.5 \%)$ & $\leq 0.001$ \\
- Yes & $60(26.8 \%)$ & $205(48.2 \%)$ & \\
\hline
\end{tabular}

$\dagger$ Chi square test

Table (3): Contraceptive Use by timing of marriage

\begin{tabular}{|c|c|c|}
\hline (2) & Married Early & Married $\geq 18 Y$ \\
\hline $\begin{array}{l}\text { Contraceptive use after first } \\
\text { child }\end{array}$ & $167(84.3 \%)$ & $322(85.2 \%)$ \\
\hline P-value ${ }^{\dagger}$ & \multicolumn{2}{|c|}{0.8} \\
\hline $\begin{array}{l}\text { Contraceptive use after second } \\
\text { child }\end{array}$ & $132(82.5 \%$ & $271(87.4 \%)$ \\
\hline $\mathrm{P}_{\text {- value }}^{\dagger}$ & \multicolumn{2}{|c|}{0.1} \\
\hline $\begin{array}{l}\text { Sources of FP methods } \\
\text { - Public } \\
\text { - Others (private, NGOs) }\end{array}$ & $\begin{array}{c}137(82.5 \%) \\
29(17.5 \%)\end{array}$ & $\begin{array}{l}218(68.1 \%) \\
102(31.9 \%)\end{array}$ \\
\hline P-value ${ }^{\dagger}$ & \multicolumn{2}{|c|}{0.001} \\
\hline
\end{tabular}

$\dagger$ Chi square test 
Table (4): Relations between contraceptive use and selected indicators

\begin{tabular}{|c|c|c|c|c|}
\hline & $\begin{array}{c}\text { Contraceptive } \\
\text { Use }\end{array}$ & Non use & P value & $\begin{array}{c}\text { Crude OR } \\
\text { (95\%CI) }\end{array}$ \\
\hline $\begin{array}{c}\text { Education } \\
\text { - Yes }\end{array}$ No & $\begin{array}{c}40(87.0 \%) \\
59(72 \%)\end{array}$ & $\begin{array}{c}64(13 \%) \\
23(28 \%)\end{array}$ & 0.001 & $2.6(1.5-4.5)$ \\
\hline $\begin{array}{c}\text { Age of marriage } \\
\text { - Early }\end{array}$ & $167(84.3 \%)$ & $31(15.7 \%)$ & 0.4 & $1.07(0.6-1.7)$ \\
\hline $18 \mathrm{Y}$ & $322(85.2 \%)$ & $56(14.8 \%)$ & & \\
\hline $\begin{array}{c}\text { Husband Education } \\
\text { - Yes }\end{array}$ & $402(86.5 \%)$ & $63(13.5 \%)$ & 0.002 & $1.7(1.1-2.9)$ \\
\hline No & $87(78.4 \%)$ & $24(21.9 \%)$ & & \\
\hline
\end{tabular}

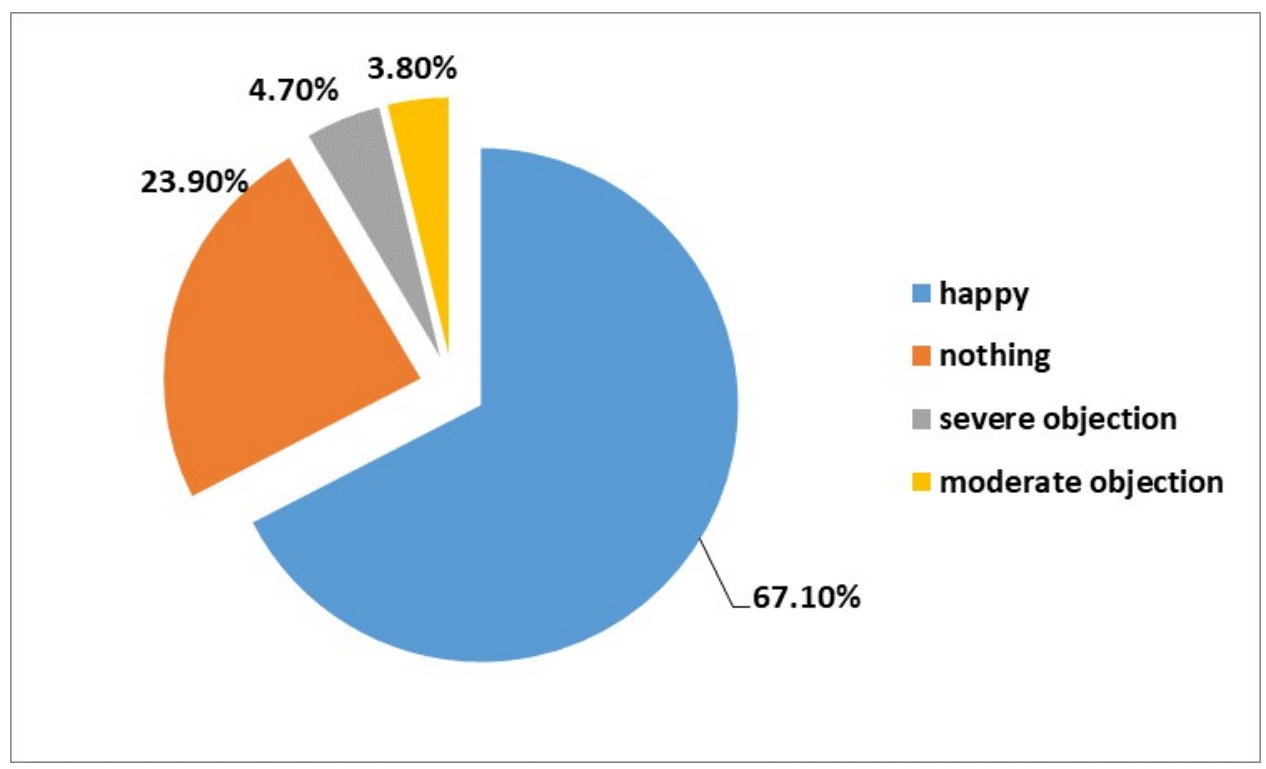

Figure (1): Reported feelings of participants about their marriage before $18 Y$ 


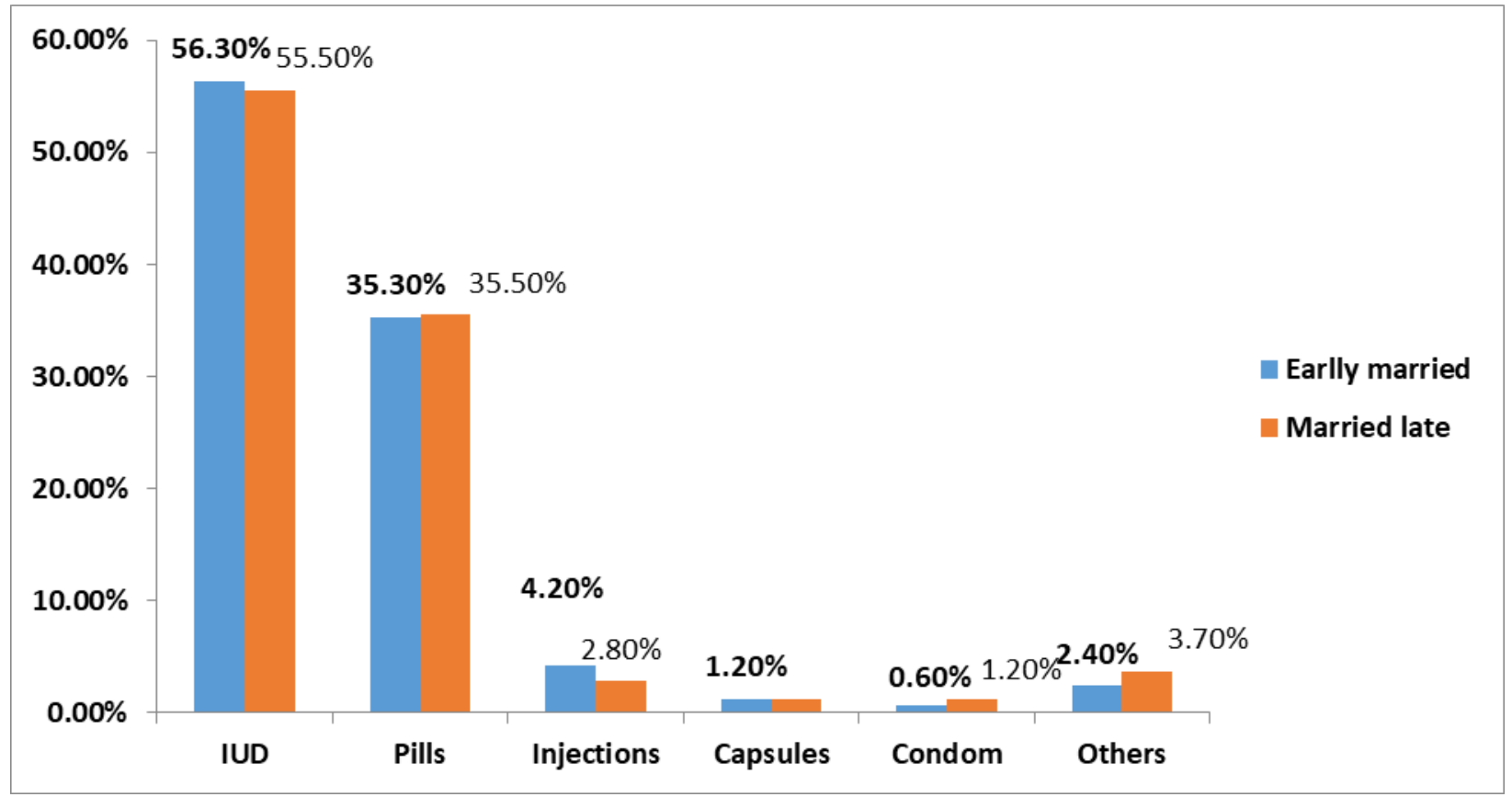

Figure (2): Family Planning Methods Use by timing of Marriage 


$$
\text { العربى الملخص }
$$

\section{تأثير سن الزواج على ممارسات تتظيم الأسرة في المناطق الريفية بمحافظة الجيزة ، مصر}

مها مو افي ، نسرين كمال الدين

يعمل تنظيم الأسرة على تحسين النتائج الصحية المتعلقة باللأمهات و الأطفال كما يعمل على خفض معدلات الأمر اض و الوفيات المرتبطة بالحمل ، وكذلك التكاليف الاقتصادية للحمل المبكر. تهدف هذه الدر اسة إلى وصف تأثير سن الزواج المبكر على السلوكيات و الممارسات الخاصة بتنظيم الأسرة .

أجريت هذه الدر اسة الإستكثافية في خمسة مر اكز للرعاية الصحية الأولية الريفية في محافظة الجيزة ، بجمهورية مصر العربية لتقدير مدى الطلب على وسائل تنظيم الأسرة بين مجمو عتين فر عيتين: الإناث المنزوجات قبل سن 18 سنة و الاتي تزوجن في 18 سنة أو أكبر. تم إجر اء عدد من المقابلات المنظمة مع 650 أنثى في سن الإنجاب، و أوضحت النتائج أن عدد مر ات الحمل وحجم الأسرة أعلى بكثير بين الإناث المنزوجات قبل 18سنة (3.3 د 1.9) و (4.8 ـ 1.6) مقابل (2.7 1.5) و (4.4 ـ 1.3). كما أوضحت أن استخدام وسائل تنظيم الأسرة بعد الطفل الأول والثاني أقل بين الإناث المتزوجات في وقت رهت مبكر (84.3 \%) و (82.5 \%) مقابل (85.2 \%) و (87.4 \%) من نظر ائهن المتزوجات في سن 18 سنة أو اكبر، على التو الي مع عدم وجود فروق ذات دلالة إحصائية. كما أظهر التحليل ثنائي المتغير أن احتمالية استخدام النساء لوسائل تنظيم الأسرة بعد الطفل الأول كانت أعلى بين النساء المتعلمات و النساء اللائي لايهن زوج منعلم مقارنة مع النساء الأميات و النساء اللائي لديهن زوج غير متعلم [COR نستخلص من هذه الدر اسة أن معدل استخدام وسائل تنظيم الأسرة كان منخفضًا بشكل خاص بين الإناث المتزوجات قبل 18 عامًا ، وبالتالي كان حجم أسر هن و عدد حملهن مرتفعًا ويعتبر التعليم أحد أهم المحددات الهامة لسن الزواج واستخدام وسائل تنظيم الأسرة. ينبغي مر اعاة هذه العو امل أثناء تصميم استر اتيجيات تنظيم الأسرة على المدى القصير و الطويل لزيادة فعالية استخدام وسائل تتظيم الأسرة بين الإناث المتزوجات في سن مبكر. الكلمات الدالة: منع الحمل ؛ تنظيم الأسرة؛ سن الزواج، الزواج المبكر. 